\title{
Pendampingan Percepatan Pengentasan Kemiskinan Melalui Budidaya Cacing Tanah (Lumbricus Rubellus) di Kecamatan Soko Kabupaten Tuban Kresna Oktafianto ${ }^{1 *}$; Raka Nur Sukma ${ }^{2}$; Kuntum Febriyantiningrum ${ }^{3}$; Dwi Oktafitria ${ }^{4}$ Henny Murnafikhoh ${ }^{5}$, Habib Al Mahdi ${ }^{6}$; Rahmatullah ${ }^{7}$ \\ ${ }^{1,6}$ Program Studi Matematika, ${ }^{2}$ Program Studi Ilmu Kelautan, ${ }^{3,4}$ Program Studi Biologi \\ ${ }^{5}$ Program Studi PGSD, ${ }^{7}$ Program Studi Teknik Informatika Universitas PGRI Ronggolawe Tuban \\ 1*kresnaoktafianto@unirow.ac.id
}

\begin{abstract}
Abstrak
Salah satu upaya pengentasan kemiskinan daerah yang ada di Kecamatan Soko Kabupaten Tuban yaitu dengan melakukan pendampingan budidaya cacing tanah (Lumbricus Rubellus). Kegiatan pendampingan budidaya cacing tanah (Lumbricus rubbelus) ditujukan kepada kelompok petani yang ada di Kecamatan Soko Kabupaten Tuban. Kegiatan Pengabdian Kepada Masyarakat (PKM) ini dilakukan dengan menggunakan metode berupa kegiatan pelatihan budidaya cacing tanah (Lumbricus rubbelus) yang dimulai dari pemberian materi, persiapan media cacing tanah, penaburan benih, pembuatan pakan, pemberian pakan, perawatan rutin, teknik panen serta monitoring dari tim pelaksana PKM. Kegiatan pendampingan dan monitoring diamati dengan lembar instrumen observasi keterlaksanaan budidaya, lembar observasi perkembangan budidaya cacing, dan angket respon peserta. Pengabdian Kepada Masyarakat diakhiri dengan penyerahan bibit cacing tanah (Lumbricus rubbelus) kepada peserta kelompok petani yang ada di Kecamatan Soko Kabupaten Tuban sebagai modal awal memulai budidaya cacing tanah (Lumbricus rubbelus). Hasil Pengabdian Kepada Masyarakat diperoleh bahwa rata-rata responsif pembudidaya cacing tanah di Kecamatan Soko menunjukkan $4.1 \%$ amat baik, $34.8 \%$ baik, $39.8 \%$ cukup dan sisanya $21.3 \%$ masih kurang dan perlu dilakukan pembinaan dan pendampingan teknis secara kontinu agar mendapatkan hasil yang maksimal.
\end{abstract}

Kata Kunci: Budidaya, Kemiskinan, Pengentasan, Lumbricus Rubellus

\section{Abstract}

One of the efforts to alleviate poverty in Soko Sub-District, Tuban Regency is giving an assisting program in the cultivation of earthworms (Lumbricus rubellus). This program is aimed for groups of farmers in Soko Sub-District, Tuban Regency. This Community Service Activity (PKM) was carried out by using a method in the form of training activities for earthworm cultivation (Lumbricus rubbelus) starting from the provision of materials, preparation of earthworm media, seed sowing, feed making, feeding, routine maintenance, harvesting techniques and monitoring of PKM implementation team. Mentoring and monitoring activities were observed with cultivation implementation observation instruments, observation sheets on worm cultivation, and participant response questionnaires. This community service ended with the submission of earthworm seedlings (Lumbricus rubbelus) to the participants of farmer groups in Soko Sub-district, Tuban Regency as the initial capital to start earthworm cultivation (Lumbricus rubbelus). The results of Community Service showed that the average responsiveness of earthworm cultivators in Soko Subdistrict showed very good (4.1\%), good (34.8\%), sufficient (39.8\%)and the remaining was lacking and continuous technical guidance and assistance needed to get maximum results $(21.3 \%)$.

Keywords: Allevation, Cultivation, Poverty, Lumbricus Rubellus

\section{Pendahuluan}

Soko merupakan sebuah kecamatan yang terletak di Kabupaten Tuban dengan luas wilayah mencapai 96.88 $\mathrm{km}^{2}$ (BPS Tuban, 2018). Wilayah tersebut sebagian besar berupa sawah dan ladang dengan luas sebesar $7100.86 \mathrm{Ha}$, sehingga sebagian besar masyarakat yang ada di wilayah Kecamatan Soko mayoritas bermata pencaharian sebagai petani atau buruh tani, sisanya bekerja sebagai pedagang, industri, karyawan, jasa pertukangan dan lainnya. Penghasilan dari petani maupun buruh tani masih belum cukup untuk memenuhi kebutuhan sehari-hari sehingga beberapa petani ada yang bekerja tambahan sebagai kuli bangunan, buruh di pasar atau memelihara hewan ternak seperti kambing atau sapi dengan jumlah skala kecil atau skala rumahan. Dengan adanya kondisi seperti ini menyebabkan banyak pemuda desa yang mengadu nasib mencari pekerjaan yang dianggap layak di kota besar guna memenuhi kebutuhan sehari-hari.

Karena sebagian besar wilayah Soko bekerja sebagai petani maupun buruh tani pada saat musim panen padi masyarakat memiliki limbah berupa jerami padi yang jumlahnya cukup banyak dan pengelolaannya pun hanya sebatas untuk pakan ternak. Sedangkan 
kotoran hewan ternak juga belum banyak dimanfaatkan oleh masyarakat sekitar. Selama ini, petani hanya menumpuk saja kotoran hewan tersebut dan tidak mengolah atau memanfaatnya. Dan juga rendahnya kesadaran masyarakat untuk mengolah limbah rumah tangga dan limbah tumbuhan juga belum banyak dimanfaatkan dengan baik. Dalam hal ini menjadikan potensi yang besar untuk memanfaatkan pengelolaan limbah jerami padi, kotoran ternak, limbah tumbuhan dengan cara melakukan budidaya cacing tanah (Lumbricus rubellus). Cacing tanah (Lumbricus Rubellus) adalah cacing tanah yang tergolong dalam kelompok binatang invertebrata (tidak bertulang belakang) yang hidupnya di tanah yang gembur dan lembab. Cacing ini sangat mudah untuk diternak, selain itu perkembangbiakannya sangat cepat dibanding dengan jenis cacing lain. Hewan ini mempunyai potensi yang sangat menakjubkan bagi kehidupan dan kesejahteraan manusia (Hermawan, 2015:7). Sebagaimana diketahui bahwa cacing ini apabila dimasukkan ke dalam tumpukan sisa organik akan mempercepat penguraian volume sampah dan mempercepat pengomposan. Cacing tanah mempunyai kemampuan merombak limbah organik dengan memanfaatkan limbah organik tersebut sebagai sumber makanan cacing dengan memakan sebanyak $100 \%$ makanan setiap hari dari berat tubuhnya (Rusmini, 2016). Cacing tanah adalah sumber protein sangat tinggi dengan kadar sekitar 76\%. Kadar ini lebih tinggi dibandingkan daging mamalia (65\%) atau ikan (50\%). Cacing tanah juga mengandung beberapa kadar komponen lain, seperti $17 \%$ karbohidrat, $45 \%$ lemak, dan abu 1,5 \% (Rusmini, 2016). Adapun manfaat dari cacing tanah menurut Hermawan $(205 ; 45)$ memberikan manfaat untuk antibakteri, obat alami tanpa efek samping, obat untuk tifus, parasetamol alami, penghancur gumpalan darah dan bahan kosmetik.

Budidaya cacing tanah tidak banyak memakan waktu karena masa berkembang biak atau siap kawin cacing tanah setelah berumur 2-3 bulan terhitung semenjak menetas dari kokon. Namun masa produktif cacing dewasa terjadi pada umur 4-11 bulan, yakni ketika cacing tanah sudah mempunyai alat perkembangbiakan yang disebut dengan klitelum. Klitelum yang terlihat seperti cincin ini sebenarnya merupakan bagian tubuh yang menebal dan letaknya pada segmen 26-32 dari bagian atas tubuh cacing tanah. Warnanya lebih terang dibandingkan warna tubuh lainnya. Klitelum inilah yang akan mengeluarkan protein dan membentuk kokon setelah terjadi proses perkawinan silang (Siska, 2017).

Selain itu budidaya cacing tanah juga tidak perlu membersihkan kandang karena kotoran cacing tanah tersebut akan berfungsi sekaligus sebagai pupuk organik yang berkualitas tinggi. Berdasarkan hal tersebut di atas maka wilayah kecamatan Soko Kabupaten Tuban sangat baik untuk membudidayakan cacing tanah sebagai sumber tambahan mata pencaharian. Sehingga dalam hal ini Universitas PGRI Ronggolawe Tuban yang bekerja sama dengan Bapedda Tuban mengadakan kegiatan Pengabdian Kepada Masyarakat dengan judul Pendampingan Percepatan Pengentasan Kemiskinan Melalui Budidaya Cacing Tanah (Lumbricus rubellus) di Kecamatan Soko Kabupaten Tuban.

\section{Metode Pelaksanaan}

Kegiatan Pengabdian Kepada Masyarakat ini dilaksanakan mulai dari pemberian materi dan praktek, pendampingan, monitoring dan evaluasi kegiatan selama kegiatan berlangsung. Berikut disajikan ringkasan kegiatan pelaksanaan Pengabdian Kepada Masyarakat:

a. Pemberian materi tentang cacing tanah, budidaya cacing tanah, persiapan media cacing tanah, pembuatan kandang atau rumah cacing tanah,

b. Pemberian materi tentang pembuatan pakan dan pemilahan sampah atau limbah yang bisa diolah untuk pakan cacing tanah, teknik panen cacing tanah, bisnis plan budidaya cacing tanah

c. Praktek pembuatan media untuk cacing tanah, kandang untuk cacing tanah, pembuatan pakan untuk cacing tanah dan perawatan rutin untuk cacing tanah

d. Pemberian angket respon peserta

e. Monitoring dan evaluasi perkembangan budidaya cacing tanah pasca pelatihan dan pendampingan

\section{Hasil dan Pembahasan}

Pelaksanaan Pengabdian Kepada Masyarakat

Kegiatan Pengabdian Kepada Masyarakat dilaksanakan pada Hari Minggu tanggal 03 Oktober 2018. Kegiatan PKM dilaksanakan di Balai Desa Pandan Wangi Kecamatan Soko. Pada tahap pelaksanaan PKM dimulai dari pemberian materi kemudian praktek kegiatan budidaya cacing tanah (lumbricus rubellus). Berikut disajikan beberapa dokumentasi tentang kegiatan PKM.

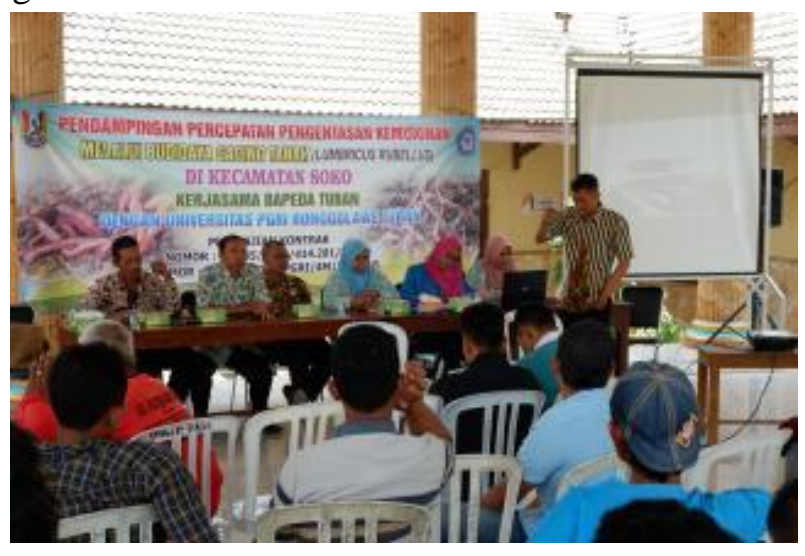

Gambar 1. Pemberian Materi Cacing Tanah 


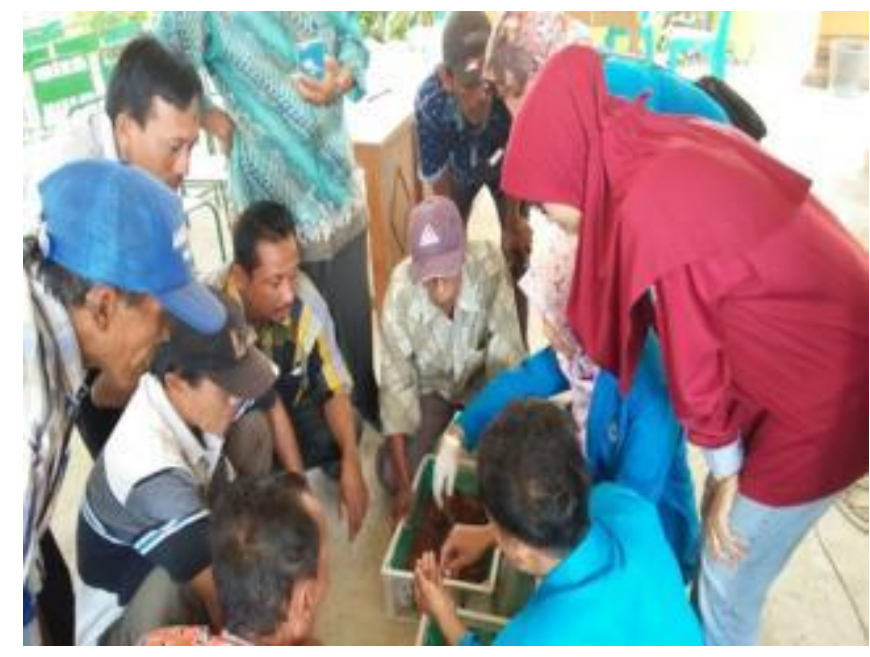

Gambar 2. Praktek pemilahan Bibit Cacing Tanah

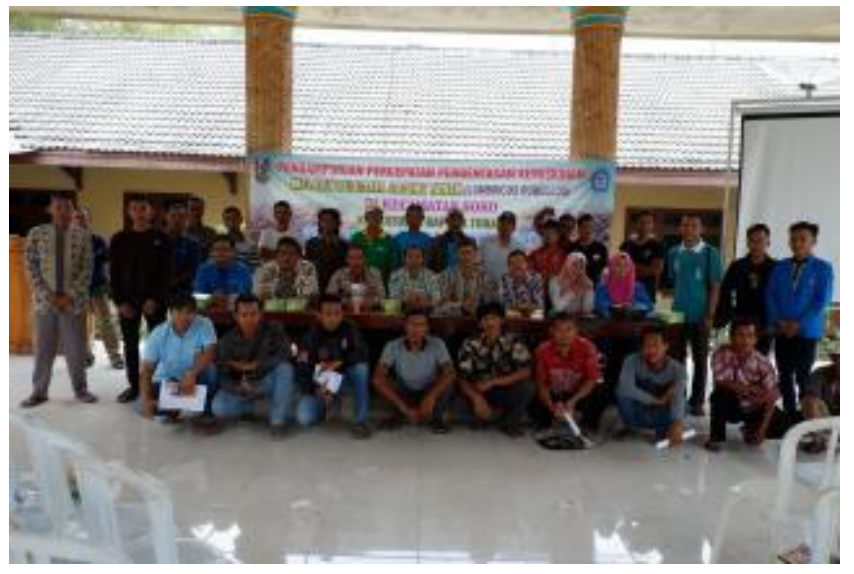

Gambar 3. Peserta Pendampingan dan Pelatihan Cacing Tanah

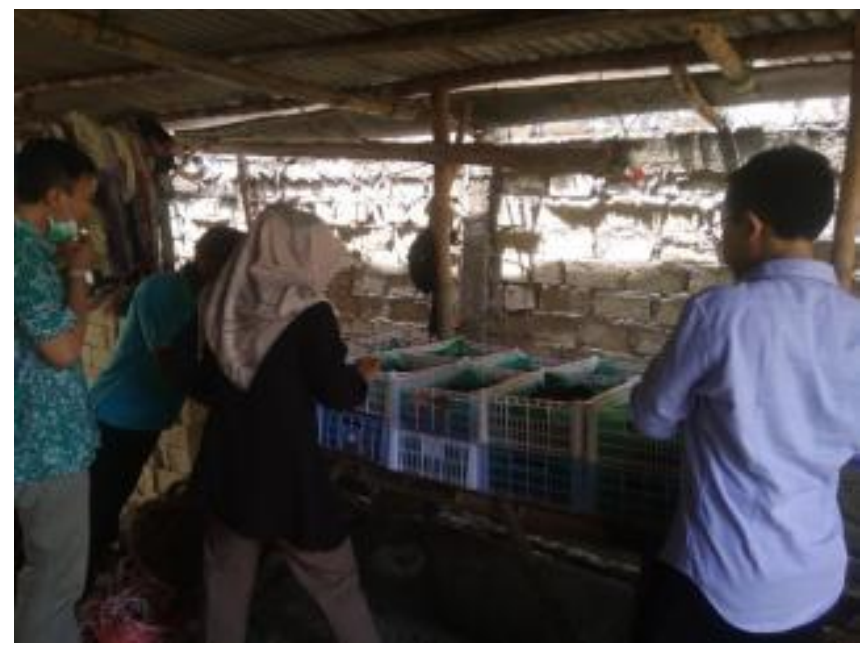

Gambar 4. Monitoring dan Evaluasi Cacing Tanah

\section{Respon Peserta}

Peserta pendampingan percepatan pengentasan kemiskinan diberikan kuisioner atau angket untuk mengetahui respon peserta terhadap pelatihan dan pendampingan budidaya cacing tanah. Berdasarkan hasil angket respon peserta diperoleh data seperti yang ditunjukkan pada tabel 1 berikut:

Tabel 1.

Rekapitulasi Angket Pendampingan Budidaya Cacing Tanah

\begin{tabular}{|c|c|}
\hline No & Pernyataan \\
\hline 1 & 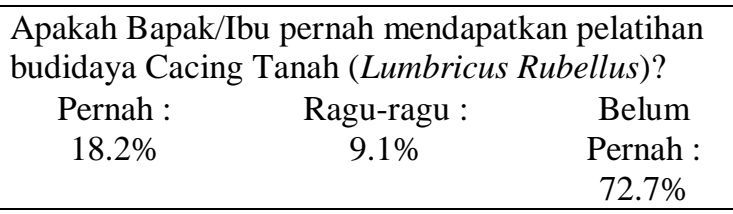 \\
\hline 2 & $\begin{array}{l}\text { Apakah bahan-bahan yang dibutuhkan untuk } \\
\text { budidaya Cacing Tanah (Lumbricus Rubellus)? } \\
\begin{array}{l}\text { Mudah : } \\
90.9 \%\end{array}\end{array}$ \\
\hline 3 & $\begin{array}{l}\text { Bagaimana menurut Bapak/Ibu tentang pelatihan } \\
\text { budidaya Cacing Tanah (Lumbricus Rubellus)? } \\
\begin{array}{l}\text { Mudah : } \\
45.5 \%\end{array}\end{array}$ \\
\hline 4 & $\begin{array}{l}\text { Bagaimana menurut Bapak/Ibu tentang } \\
\text { kebermanfaatan pelatihan budidaya Cacing Tanah } \\
\text { (Lumbricus Rubellus)? } \\
\text { Bermanfaat: Sedang : } 22.7 \% \text { Kurang : } 0 \% \\
\quad 77.3 \%\end{array}$ \\
\hline 5 & $\begin{array}{l}\text { Setelah mengikuti pelatihan ini, apakah Bapak/Ibu } \\
\text { tertarik dan berniat mengembangkan budidaya } \\
\text { Cacing Tanah (Lumbricus Rubellus) di rumah? } \\
\begin{array}{ccc}\text { Ya : 68.2\% } & \text { Ragu-ragu : } & \text { Tidak : } 0 \% \\
31.8 \% & \end{array}\end{array}$ \\
\hline 6 & $\begin{array}{l}\text { Setelah mengikuti pelatihan ini, apakah Bapak/Ibu } \\
\text { akan mencoba budidaya Cacing Tanah (Lumbricus } \\
\text { Rubellus) untuk dipasarkan? } \\
\text { Ya: } 90.9 \% \text { Ragu-ragu : } 9.1 \% \text { Tidak : } 0 \%\end{array}$ \\
\hline
\end{tabular}

Berdasarkan data hasil angket pendampingan pengentasan percepatan budidaya cacing tanah pada tabel 1 dapat dikatakan bahwa peserta pendampingan budidaya cacing tanah secara umum belum pernah mendapatkan pelatihan sebelumnya yaitu $72.7 \%$, namun antusias mengikuti pelatihan sangat merespon positif terhadap kegiatan pendampingan cacing tanah tersebut.

Untuk bahan-bahan yang dibutuhkan cacing tanah umumnya mudah didapatkan yaitu sebesar $90.9 \%$ karena sebagian besar peserta memiliki bahan-bahan yang dibutuhkan cacing tanah misalnya jerami padi, kotoran hewan ternak, limbah dedaunan atau tumbuhan dan sisa gergajian kayu yang digunakan untuk media maupun pakan cacing tanah.

Setelah mengikuti kegiatan pelatihan dan pendampingan budidaya cacing tanah diperoleh hasil bahwa pelatihan budidaya cacing tanah mudah dilakukan yaitu sebesar $45.5 \%$ dan $54,5 \%$ sedang. Untuk kebermanfaatan dari adanya pelatihan ini yaitu $77.3 \%$ mengatakan bermanfaat, sedangkan sisanya $22.7 \%$ mengatakan sedang. 
Dari tabel 1 di atas diperoleh juga bahwa sebagian besar peserta tertarik dan akan mencoba untuk mengembangkan budidaya cacing tanah karena memang cacing tanah sangat mudah untuk dibudidaya dan perwatannya juga sangat mudah dilakukan.

\section{Monitoring Pelaksanaan Budidaya dan Pendampingan Program Pengabdian Kepada Masyarakat \\ Monitoring dilakukan untuk melihat perkembangan} budidaya cacing tanah (Lumbricus Rubellus), selain itu pada saat monitoring pembudidaya dapat menanyakan keluhan maupun kendala baik secara teknis maupun non teknis yang dihadapi dalam menjalankan budidaya cacing tanah (Lumbricus Rubellus). Berdasarkan analisis penilaian kegiatan monitoring di kecamatan Soko Kabupaten Tuban dengan melakukan penyebaran instrumen responsif terhadap keseriusan dalam pengelolaan budidaya cacing tanah (Lumbricus Rubellus) berkembang dengan baik. Hal ini dapat dijelaskan pada grafik-grafik berikut:

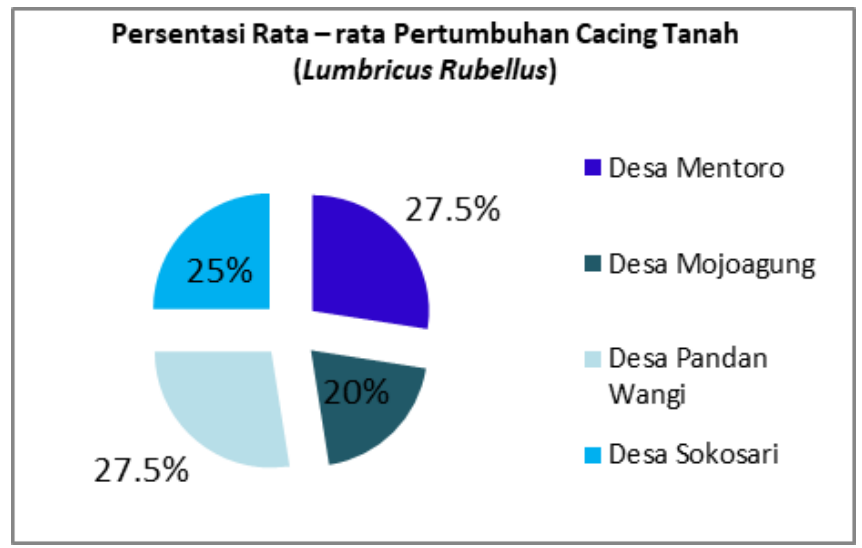

Gambar 5. Rata - rata Pertumbuhan cacing tanah (Lumbricus Rubellus) dari Penyebaran Instrumen di Kecamatan Soko

Monitoring budidaya cacing tanah (Lumbricus Rubellus) di Kecamatan Soko dilakukan di Desa Mentoro, Desa Mojoagung, Desa Sokosari, dan Desa Pandan Wangi. Warga yang menerima bantuan bibit cacing berjumlah 27 orang, dari ke empat Desa tersebut dapat dinilai pertumbuhan cacing tanah (Lumbricus Rubellus) sangat baik terdapat pada Desa Mentoro dan Pandan Wangi dengan pertumbuhan yang sama karena dilakukan dengan perlakuan yang cukup baik, sedangkan Desa dengan responsif terendah terjadi pada Desa Mojoagung.

\section{Kesimpulan dan Saran}

Kegiatan Pendampingan Percepatan Kemiskinan melalui Pengabdian Kepada Masyarakat melalui budidaya cacing tanah (Lumbricus rubellus) sudah berjalan dengan baik yang ditunjukkan bahwa rata-rata responsif pembudidaya cacing tanah di Kecamatan Soko menunjukkan $4.1 \%$ amat baik, $34.8 \%$ baik, $39.8 \%$ cukup dan sisanya $21.3 \%$ masih kurang dan perlu dilakukan pembinaan dan pendampingan teknis secara kontinu agar mendapatkan hasil yang maksimal. Kegiatan PKM ini dilakukan melalui tahapan yaitu pemberian materi dan praktek, kemudian dilanjutkan dengan pendampingan serta monitoring sampai tahap perawatan dan pemeliharaan. Tujuan kegiatan budidaya cacing tanah (Lumbricus rubellus) sudah tercapai dengan baik, yaitu sebagai pembelajaran , mensejahterakan dan menciptakan peluang usaha guna meningkatkan perekonomian masyarakat desa khususnya di wialayah Kecamatan Soko Kabuaten Tuban.

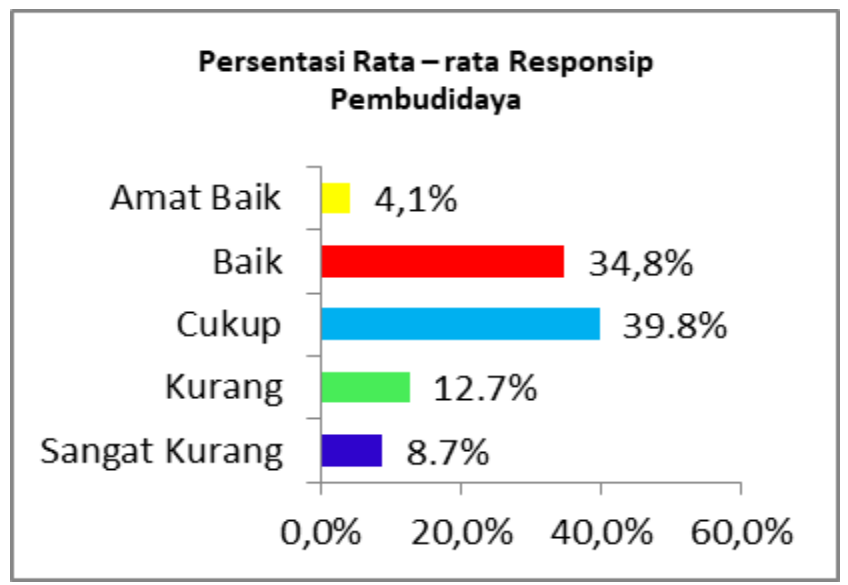

Gambar 6. Rata - rata Responsip Berdasarkan Penyebaran Instrumen di Kecamatan Soko

Adapun faktor yang mendukung dari adanya kegiatan program budidaya cacing adalah partisipasi yang tinggi dari masyarakat wilayah Kecamatan Soko Kabupaten Tuban. Sedangkan untuk faktor yang menghambat dari pelaksanaan program budidaya cacing adalah terdapat hama tikus dan semut yang sering menyerang cacing serta dibutuhkan waktu yang lama saat dilakukan penggantian media.

\section{Ucapan Terima Kasih}

Terimakasih kepada Bappeda Tuban yang telah menyediakan dana dan sebagai mitra dari tim Pengabdian Kepada Masyarakat Universitas PGRI Ronggolawe Unirow Tuban serta masyarakat di wilayah Kecamatan Soko Kabupaten Tuban yang telah mengikuti kegiatan pendampingan dan budidaya cacing tanah dengan baik serta antusias.

\section{Daftar Rujukan}

Anonim, (2014). AK 9 Worm House Perum Bukit Karang AK No.9 Tuban. Program Kemitraan Budidaya Cacing Lumbricus Rubellus.

Badan Pusat Statistik Kabupaten Tuban. (2018). Kecamatan Soko Dalam Angka 2018. Tuban: BPS Kabupaten Tuban. 
Hermawan, Rudi. (2015). Usaha Budidaya Cacing Lumbricus Multiguna dan Prospek Ekspor Tinggi. Yogyakarta: Pustaka Baru press.

Resiana, Siska. (2017). Pemberdayaan Masyarakat Melalui Pelatihan Usaha Budidaya Cacing Lumbricus Rubellus di Desa Kumpulrejo Kecamatan Argomulyo Kota Salatiga. Skripsi Universitas Negeri Semarang; Semarang.

Rusmini, Rusmini. (2016). Pelatihan Budidaya Cacing Tanah (Lumbricus Rubellus) Bagi Para Tani Desa Sumberdukun, Ngariboyo,Magetan. Jurnal Abdi. Vol.1, No.2 Januari 2016, hal 114-120. 